\title{
Characteristics of 4-Stroke Single Cylinder Ci Engine using Cotton Seed Oil Blended With Diesel
}

\section{Thiagarajan, K. SurendraBabu, Vamsi Shankar. Saiprasanth, Venkatesh Kumar}

\begin{abstract}
In four different compositions a cotton oil methyl ester is prepared and combine with diesel, ranging from $5 \%$ to $20 \%$ in $5 \%$ stages Tests were performed at a constant speed of 1500 rpm in a single cylinder variable compression ratio diesel engine. The highest thermal brake output and the lowest specific fuel consumption was observed for a compression ratio of 15 and 17 percent of the biodiesel blend. At a compression ratio of 17, the average emission of nitric oxide was 205 ppm and the total emission of diesel was 155 ppm. Significant decrease in emissions of smoke and carbon monoxide was observed in the maximum load range and compression ratio. For the prepared biodiesels, enhanced heat release characteristics have been noted. The results show that the biodiesels can be safely utilized without any modification of engine ..
\end{abstract}

Keywords : emission, biodiesel, cotton seed oil, combustion, compression ratio.

\section{INTRODUCTION}

Diesel engines are widely used all over the world. They form the basis of development in the fields of transportation, agriculture, manufacturing industries and energy production power plants[1]. The increasing dependence on diesel, but decreasing diesel reserves demands the need for a substitute fuel for diesel. The substitution of fuel is biodiesel which is made up of animal fats as well as vegetable oil[2]\&[3]. It can act both as substitute and an additive to diesel fuel. They have their cetane numbers and many other chemical properties closer to that of diesel[4].

Biodiesel is obtained from vegetable oil by transesterification process. They having no sulphur content are biodegradable, non-toxic and natural lubricants[5]. They also have their flash point above $130^{\circ} \mathrm{C}$ making safer to handle, thus forming popular alternative for diesel[6]. Significance of biodiesel increases are:

i. Limited fossil fuel reserves.

ii. Renewability of biodiesel.

Revised Manuscript Received on December 16, 2019

* Correspondence Author

C .Thiagarajan Associate Professor*, Department of Mechanical Engineering Aarupadai Veedu Institute of Technology Vinayaka Mission Research Foundation.Email.cthiagarajan@avit.ac.in

K.Surendrababu, Associate Professor Department of Mechanical Engineering Aarupadai Veedu Institute of Technology Vinayaka Mission Research Foundation Email: surendrababu@avit.ac.in

VamshiShankar, Saiprasanth, Venkatesh Kumar, UG Sholar, Department of Mechanical Engineering, Aarupadai Veedu Institute of Technology, Vinayaka Mission's Research Foundation. iii. Increasing petroleum prices.

iv. Self-lubricating property of biodiesel

v. Environmental benefits of biodiesel.

\section{PROBLEM STATEMENT}

It is known that the remaining diesel reserves of the world can get exhausted in a maximum of 200 years, when consumed at the current levels. But diesel engines cannot be totally kept aside, as they play key role in our developmental path. This arises the need to look for an alternate fuel for diesel, which can bring down diesel extraction rates, diesel consumption rates, as well as the pollution rates due to diesel combustion[7]. The present rate of consumption of petroleum and diesel fuels are at an alarmingly high value, which causes a major environmental issue, "The Global Warming". It means that the average temperature of the entire globe is increasing, which results in further complicated issues. The glaciers at the poles melt and thus increases the water level I the seas and oceans. This increased water level floods many landmasses all around the world[9].

Combination of biodiesels from Cotton seed oil and diesel can satisfy the power demands from the diesel engine, with least engine modifications. But, the most efficient combination of these biodiesels and diesel, to be used as a bio fuel, has to be derived on the basis of experimental analysis[10]."To make a comparative study of the performance properties of a 4 stroke single cylinder diesel engine using various blends of biodiesels from Cotton seed along with diesel, and to establish the relevance of usage of biodiesels[11]."

The experimental procedure is to run the four stroke Single cylinder Diesel Engine using various combinations of Cotton seed and diesel[12]. The load test is passed through the Compression Ignition engine and the enlisted properties are calculated:

- Mechanical efficiency

- Brake thermal efficiency

- Indicated thermal efficiency.

\section{MATERIALS AND METHODS}

The experimental investigation is carried out on water cooled; direct injection, four stroke, single cylinder diesel engine. The engine operates at a constant speed of $1500 \mathrm{rpm}$. Lubrication oil levels were examined before starting the engine. Additionally, the

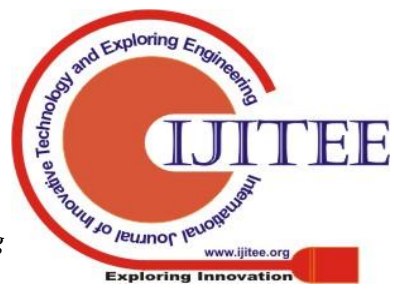


biodiesels used were self-lubricating type. The major modules of the this setup are fuel tank, cooling system, exhaust gas line, engine and by-pass line performance calculation of equipment. The engine is coupled with a manual loading system. The manual loading is utilized for loading the engine via weights load bank so that the engine can be operated under varying loads. The fuel tank is connected to the engine via fuel line with a fuel controlling valve. The fuel is pumped by a fuel pump to the fuel injector[13].

Preparation of various combinations of biodiesel with diesel blends was the first step. After deciding the required combination ratios, the biodiesels from Cotton seed were separately collected. To prepare the blends, the individual biodiesels were separately measured in required quantities using a measuring jar, and then transferred to a beaker, followed by the addition of required quantity of diesel. The mixture was then thoroughly stirred using a stirrer, so as to obtain a uniform solution. The fuel is introduced into the fuel tank of the diesel engine, after draining out the diesel previously present inside the fuel tank of the engine[14].

Maximum load on the diesel engine was calculated under the rated conditions of $1500 \mathrm{rpm}$ and a brake power of 3.7 $\mathrm{Kw}(5 \mathrm{hp})$.Engine is started at no load by cranking and left frees to run at no load condition for about 2 minutes. This was done to achieve stable running conditions for the engine. The head difference was also measured from U-tube manometer. Load and spring balance readings were also noted down. The engine speed was also measured at each loads using the tachometer. The experiment was repeated for varying loads of $2 \mathrm{~kg}, 4 \mathrm{~kg}, 6 \mathrm{~kg}, 8 \mathrm{~kg}, 10 \mathrm{~kg}$ and $12 \mathrm{~kg}$.

The fuel tank was then emptied and introduced with the new combination of fuel. The above procedure was repeated for varying combinations of fuels. The diesel engine was then stopped by cutting off the fuel supply.

Calculations were carried out using obtained values and the results were tabulated. At first, the engine is run using conventional diesel fuel without any biodiesel blends and the performance characteristics are observed and noted. After the initial experiment using conventional diesel fuel, the engine is run using varying combinations of biodiesel blends with diesel. The individual proportion of each of the biodiesels was also varied. The performance characteristics for varying loads of the varying combinations of biodiesel blends were also observed and noted as follows:

Case 1: $100 \%$ of Diesel as fuel:

In this case, the engine was run on $100 \%$ diesel as fuel at varying loads and the performance characteristics were noted.

Case 2: B20 biodiesel as fuel:

In this case, the engine was run on B20 fuel, which is a combination of $80 \%$ diesel and $20 \%$ biodiesel, with $10 \%$ each of the biodiesels from Cotton seed. The performance characteristics are noted for varying loads.

Case 3: B40 biodiesel as fuel:

In this case, the engine was run on B40 fuel, which is a combination of $60 \%$ diesel and $40 \%$ biodiesel, with $10 \%$ of biodiesel from Cotton seed. The performance characteristics are noted for varying loads. Figure 1 shows the cotton seeds. Case 4: B40 biodiesel as fuel:

In this case, the engine was run on B40 fuel, which is a combination of $60 \%$ diesel and $40 \%$ biodiesel, with $20 \%$ of biodiesel from Cotton seed. The performance characteristics are noted for varying loads.

Case 5: B40 biodiesel as fuel:

In this case, the engine was run on B40 fuel, which is a combination of $60 \%$ diesel and $40 \%$ biodiesel, with $30 \%$ of biodiesel from Cotton seed. The performance characteristics are noted for varying loads.

Case 6: B50 biodiesel as fuel:

In this case, the engine was run on B50 fuel, which is a combination of $50 \%$ diesel and $50 \%$ biodiesel, with $10 \%$ of biodiesel from Cotton seed. The performance characteristics are noted for varying loads.

Case 7: B50 biodiesel as fuel:

In this case, the engine was run on B50 fuel, which is a combination of $50 \%$ diesel and $50 \%$ biodiesel, with $25 \%$ of biodiesel from Cotton seed. The performance characteristics are noted for varying loads.

Case 8: B50 biodiesel as fuel:

In this case, the engine was run on B50 fuel, which is a combination of $50 \%$ diesel and $50 \%$ biodiesel, with $40 \%$ of biodiesel from Cotton seed. The performance characteristics are noted for varying loads.

Case 9: B60 biodiesel as fuel:

In this case, the engine was run on B60 fuel, which is a combination of $40 \%$ diesel and $60 \%$ biodiesel, with $10 \%$ of biodiesel from Cotton seed. The performance characteristics are noted for varying loads.

Case 10: B60 biodiesel as fuel:

In this case, the engine was run on B60 fuel, which is a combination of $40 \%$ diesel and $60 \%$ biodiesel, with $30 \%$ of biodiesel from Cotton seed. The performance characteristics are noted for varying loads.

Case 11: B60 biodiesel as fuel:

In this case, the engine was run on B60 fuel, which is a combination of $40 \%$ diesel and $60 \%$ biodiesel, with $50 \%$ of biodiesel from Cotton seed. The performance characteristics are noted for varying loads.

Case 12: B80 biodiesel as fuel:

In this case, the engine was run on B80 fuel, which is a combination of $20 \%$ diesel and $80 \%$ biodiesel, with $40 \%$ of biodiesel from Cotton seed. The performance characteristics are noted for varying loads.

The major goal is to carry out a the characteristics of operating efficiency and performance characteristics of a conventional diesel engine, fuelled with varying combinations of biodiesels from Cotton seed, blended with diesel. Table I shows the Comparison of Cotton seed Oil with Other Vegetable Oil 


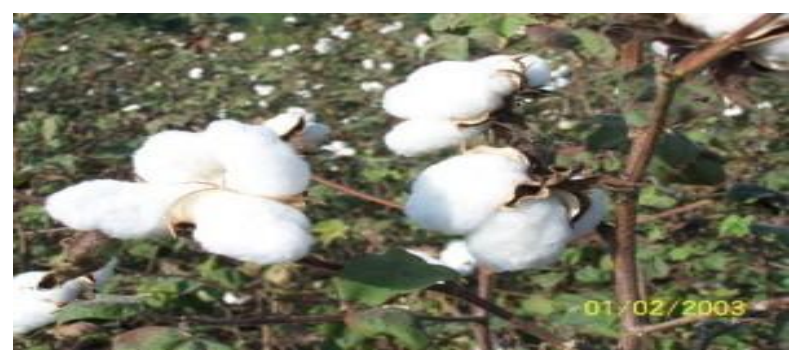

Fig. 1.Cotton Seed .

Table- I: Comparison of Cotton seed Oil with Other Vegetable Oil

\begin{tabular}{|c|c|c|c|c|c|c|c|}
\hline \multirow[t]{2}{*}{ Type } & \multirow{2}{*}{$\begin{array}{l}\text { Saturated } \\
\text { fatty acids }\end{array}$} & \multicolumn{2}{|c|}{ Monounsaturated fatty acids } & \multicolumn{3}{|c|}{ Polyunsaturated fatty acids } & \multirow[t]{2}{*}{ Smoke point } \\
\hline & & Total mono & $\begin{array}{c}\text { Oleic acid } \\
(\omega-9)\end{array}$ & Total poly & $\begin{array}{c}\text { linolenic acid } \\
(\omega-3)\end{array}$ & $\begin{array}{c}\text { Linoleic acid } \\
(\omega-6)\end{array}$ & \\
\hline Avocado & 11.6 & 70.6 & & 13.5 & 1 & 12.5 & $249^{\circ} \mathrm{C}\left(480^{\circ} \mathrm{F}\right)$ \\
\hline Canola & 7.4 & 63.3 & 61.8 & 28.1 & 9.1 & 18.6 & $238^{\circ} \mathrm{C}\left(460^{\circ} \mathrm{F}\right)$ \\
\hline Coconut & 82.5 & 6.3 & 6 & 1.7 & & & $175^{\circ} \mathrm{C}\left(347^{\circ} \mathrm{F}\right)$ \\
\hline Corn & 12.9 & 27.6 & 27.3 & 54.7 & 1 & 58 & $232{ }^{\circ} \mathrm{C}\left(450{ }^{\circ} \mathrm{F}\right)$ \\
\hline $\begin{array}{l}\text { Cotton } \\
\text { seed }\end{array}$ & 25.9 & 17.8 & 19 & 51.9 & 1 & 54 & $216^{\circ} \mathrm{C}\left(420^{\circ} \mathrm{F}\right)$ \\
\hline
\end{tabular}

\section{A. CI ENGINE APPARATUS}

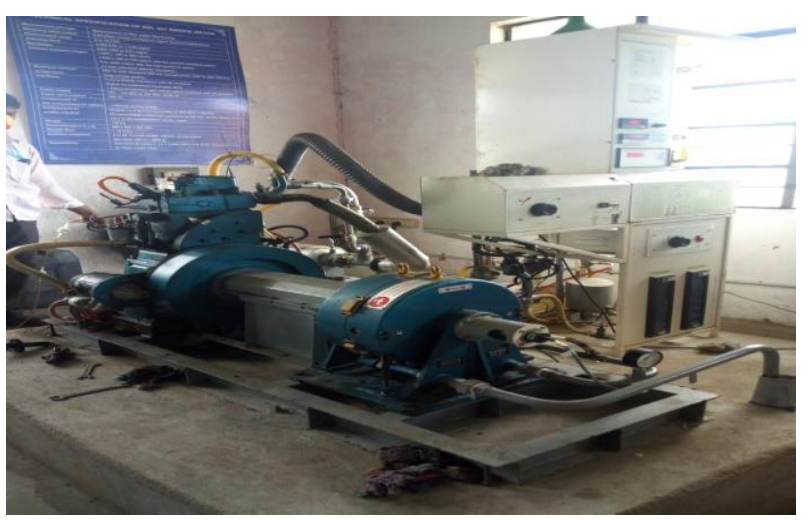

Fig. 2.CI Engine .

Figure 2 shows the CI Engine. Number Load test on 4-stroke Single Cylinder Compression Ignition Engine is conducted as per the following procedure: Calculate maximum load from name plate details Check engine for fuel availability, lubricant and cooling water connection. The Indicated thermal efficiency is calculated first. It is the ratio between indicated power and heat supplied by the combustion of fuel. To do this, we need to find out indicated power, brake power and frictional power. We first calculate the maximum load which the diesel engine can withstand under the rated brake power and rated rpm.

$\mathrm{W}=(\mathrm{P} \times 60 \times 1000) /(2 \times \pi \times \mathrm{N} \times \mathrm{r})$

Where $\mathrm{W}=$ maximum $\operatorname{load}(\mathrm{N})$

$\mathrm{P}=$ Brake power $(\mathrm{KW})$

$\mathrm{N}=$ Speed of engine (rpm)

$\mathrm{r}=$ net radius of brake drum $(\mathrm{m})$

The maximum load calculated using the above equation can be used to find the maximum torque developed within the system.

\section{$\mathrm{T}=(\mathrm{W}-\mathrm{S}) \times \mathrm{r} \times \mathrm{g}$}

Where $\mathrm{T}=$ net torque developed $(\mathrm{Nm})$

$\mathrm{S}=$ spring load $(\mathrm{kg})$

$\mathrm{g}=$ acceleration due to gravity $(\mathrm{m} / \mathrm{s} 2)$

Brake power is the power obtained at output shaft. Now, we can find the brake power $(\mathrm{Pb})$ developed within the system using the following equation

$\mathrm{Pb}=(2 \times \pi \times \mathrm{N} \times \mathrm{T}) /(60 \times 1000)$

The indicated power is the sum of brake power and frictional power (obtained by Williamson's method).

$\mathrm{Pi}=\mathrm{Pb}+\mathrm{Pf}$

The other term required in calculating the Indicated thermal efficiency is Total fuel consumption and specific fuel consumption.

Specific fuel consumption (SFC) is a measure of how efficiently the fuel supplied to the engine is used to produce power. It is defined as the fuel flow rate per unit power output, and can be expressed as

\section{$\mathrm{SFC}=\mathrm{TFC} / \mathrm{Pb}$}

Where, TFC is the Total fuel Consumption which is expressed as

$\mathrm{TFC}=(\mathrm{x} \times 3600 \times \mathrm{s}) /(\mathrm{t} \times 1000)$

Now, To find the efficiency of Indicated Thermal , Indicated thermal Efficiency $=(\mathrm{Pi} \times 3600) /(\mathrm{TFC} \times \mathrm{CV})$ Where, $\mathrm{CV}$ is the calorific value of engine fuel used.

Mechanical efficiency $(\eta \mathrm{m})=($ Brake Power $) /($ Indicated Power $)=\mathrm{Pb} / \mathrm{Pi}$

Brake Thermal Efficiency is utilized to calculate the energy from fuel to mechanical and it is defined as

Brake thermal efficiency of an IC engine is calculated by, Brake thermal efficiency ( $\boldsymbol{\eta}$ bth)

$=\mathrm{Pb} /(\mathrm{TFC} \times \mathrm{CV})$. 


\section{ANALYSIS AND CALCULATION}

Various combinations of Cotton seed Biodiesel and Diesel are prepared and set for conducting experiments. Figure 3 shows the Fig. 3. Various combinations of Diesel and Biodiesel .

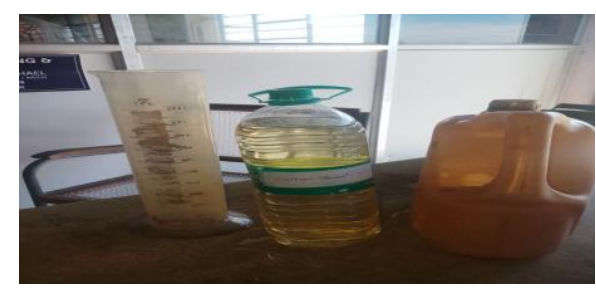

Fig. 3.Various combinations of Diesel and Biodiesel .

The series of experiments involving conducting the experiments at various loads was successfully completed, and all the readings including the loading, spring balance readings, fuel consumption, engine speed are noted and tabulated for all 12 cases of operation. All the concerning calculations are done, and important values such as Indicated power, Brake power, Total Fuel Consumption, Specific Fuel Consumption and overall operating efficiencies such as Brake Thermal Efficiencies, Indicated Thermal Efficiencies and Mechanical Efficiencies are calculated as follows in TableI, Table II, Table III, Table IV, Table V:

Table- II: Comparison VCR ENGINE- TESTNG RESULTS- HOLE NOZZLE COTTON SEED OIL $20 \%+80 \%$ DIESEL

\begin{tabular}{|l|l|l|l|l|}
\hline $\begin{array}{l}\text { Name of the } \\
\text { items }\end{array}$ & \multicolumn{4}{|c|}{ LOAD/BP } \\
\hline & 0 & 3 & 6 & 9 \\
\hline CO & 0.02 & 0.63 & 0.03 & 0.04 \\
\hline HC & 1 & 2 & 4 & 2 \\
\hline CO2 & 0.6 & 0.80 & 1.00 & 1.2 \\
\hline O2 & 19.97 & 19.64 & 19.54 & 19.15 \\
\hline NOX & 39 & 90 & 127 & 141 \\
\hline SFC & 0 & 0.62 & 0.38 & 0.13 \\
\hline BTE & 0 & 15.3 & 22.7 & 27.6 \\
\hline
\end{tabular}

Table- III: SEED OIL 40\%+60\% DIESEL

\begin{tabular}{|l|l|l|l|l|}
\hline $\begin{array}{l}\text { Name of } \\
\text { the items }\end{array}$ & \multicolumn{4}{|c|}{ LOAD/BP } \\
\hline & 0 & 3 & 6 & 9 \\
\hline $\mathrm{CO}$ & 0.01 & 0.02 & 0.02 & 0.02 \\
\hline $\mathrm{CO}$ & 0.020 & 0.02 & 0.02 & 0.02 \\
\hline $\mathrm{HC}$ & 3 & 4 & 2 & 3 \\
\hline $\mathrm{CO} 2$ & 0.6 & 0.7 & 1.00 & 1.3 \\
\hline $\mathrm{O} 2$ & 20.00 & 19.95 & 19.52 & 19.16 \\
\hline $\mathrm{NOX}$ & 37 & 76 & 186 & 148 \\
\hline SFC & 0 & 0.58 & 0.37 & 0.32 \\
\hline BTE & 0 & 15 & 23 & 26.2 \\
\hline
\end{tabular}

Table- IV: COTTON SEED OIL 60\%+40\% DIESEL

\begin{tabular}{|l|l|l|l|l|}
\hline $\begin{array}{l}\text { Name of } \\
\text { the items }\end{array}$ & \multicolumn{5}{|c|}{ LOAD/BP } \\
& & 3 & 6 & 9 \\
& 0 & & & \\
\hline CO & 0.01 & 0.02 & 0.02 & 0.02 \\
\hline HC & 3 & 1 & 2 & 5 \\
\hline CO2 & 0.6 & 0.8 & 1.00 & 1.5 \\
\hline O2 & 20.01 & 19.85 & 19.51 & 18.93 \\
\hline NOX & 38 & 82 & 125 & 168 \\
\hline SFC & 0 & 0.58 & 0.4 & 0.33 \\
\hline BTE & 0 & 14.8 & 21.6 & 26.3 \\
\hline
\end{tabular}

Table- V: DIESEL READING

\begin{tabular}{|l|l|l|l|l|}
\hline $\begin{array}{l}\text { Name of the } \\
\text { items }\end{array}$ & \multicolumn{5}{|c|}{ LOAD/BP } \\
\hline & 0 & 3 & 6 & 9 \\
& & & & \\
\hline $\mathrm{CO}$ & 0.02 & 0.02 & 0.03 & 0.02 \\
\hline $\mathrm{HC}$ & 2 & 1 & 7 & 6 \\
\hline $\mathrm{CO} 2$ & 0.05 & 0.06 & 1.00 & 1.00 \\
\hline NOX & 25 & 44 & 118 & 126 \\
\hline SFC & 0 & 0.6 & 0.39 & 0.27 \\
\hline BTE & 0 & 14.2 & 22.1 & 31.7 \\
\hline
\end{tabular}

\section{RESULT AND DISCUSSION}

From the recorded results, observations and subsequent analysis, characteristic curves are plotted against the respective load values for each of the cases of engine operation, which are:

(i)Diesel engine operating on $100 \%$ diesel as fuel

(ii) Diesel engine operating on B20 biodiesel as fuel

(iii) Diesel engine operating on B40 biodiesel(with varying blends) as fuel

(iv) Diesel engine operating on B60 biodiesel(with varying blends) as fuel

The performance of the diesel engine on the basis of important parameters of operation such as indicated thermal efficiency, brake thermal efficiency, mechanical efficiency, exhaust gas temperature and specific fuel consumption for various values of engine load. Figure4. Shows CO v/s Load for varying biodiesel blends with constant volume of Cotton seed biodiesel

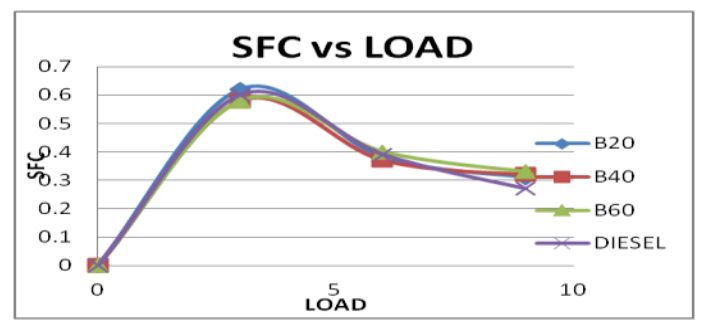

Fig. 4.COvs load for varying biodiesel blends with constant volume of Cotton seed biodiesel. 
$\mathrm{CO}$ v/s Load for varying biodiesel blends with constant volume of Cotton seed biodiesel . Figure 5,6,7,8, shows the Brake Thermal Efficiency v/s Load for varying biodiesel blends and $100 \%$ diesel., HC vs load for varying biodiesel blends with constant volume of Cotton seed biodiesel and NOX v/s Load for varying biodiesel blends and $100 \%$ diesel.

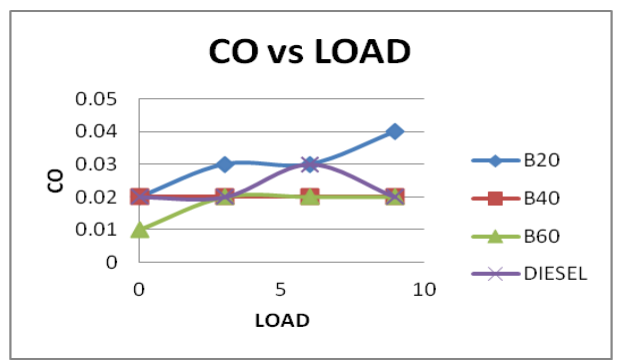

Fig. 5.Brake Thermal Efficiency v/s Load for varying biodiesel blends and $100 \%$ diesel.

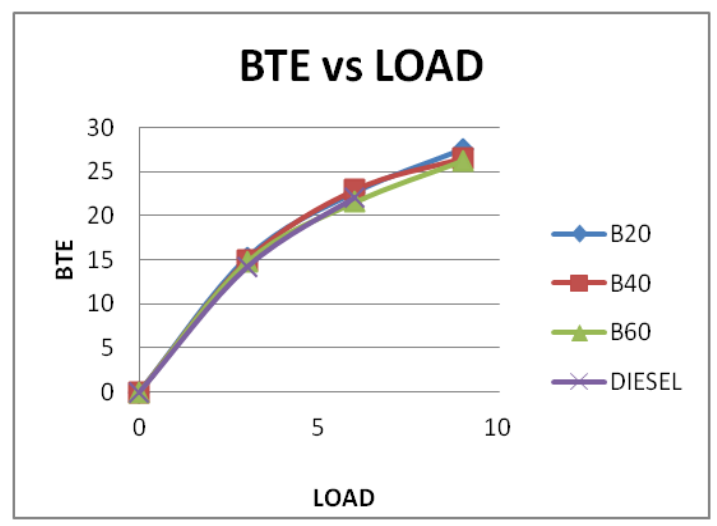

Fig. 6.HC vs load for varying biodiesel blends with constant volume of Cotton seed biodiesel.

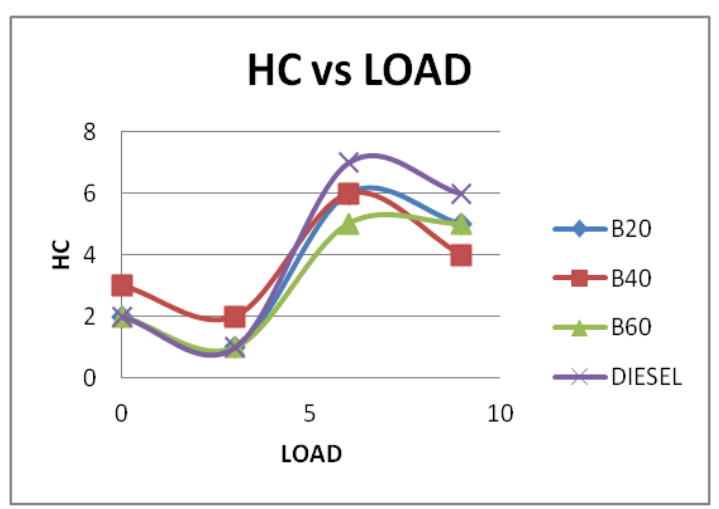

Fig. 7.NOX v/s Load for varying biodiesel blends and 100\% diesel.

\section{CONCLUSION}

After all the above results and discussions, we arrive at a few conclusions, summarized as :The specific fuel consumption of the diesel was found to be much higher than that of the biodiesels. Almost all the biodiesels had very close value of fuel consumption, but lesser than that of diesel. Hence, usage of biodiesels should help reduce the rate of fuel consumption. Individual composition of the biodiesels does not seem to play a significant role in altering the indicated thermal efficiency. It is rather a function of the Calorific value of the fuel.

In the analysis of Brake thermal efficiency, a clear 3\% to $5 \%$ improvement was shown by the biodiesels in being efficient than the $100 \%$ diesel. As it is the brake power being available at the engine output shaft, the increased brake thermal efficiency must be of noticeable use. The improvement in Brake thermal efficiency must be attributed to the additional Oxygen content and Calorific value of the biodiesels, which gave better combustion of fuels inside the chamber.

Indicated thermal efficiency was found to be higher for biodiesel blends than that for diesel. Irrespective of the combination ratio of biofuel blends, around $7 \%$ increase was observed in the case of Indicated thermal efficiency. The fuel with highest content of biodiesel had the highest efficiency, and it decreased with the decrease of biodiesel content in the fuel. Hence, it can be due to the $10 \%$ excess Oxygen content of the biodiesels which must be responsible for increasing the indicated thermal efficiency.

Mechanical efficiency was other parameter kept for evaluation of efficiency of biodiesels. When the experimental results were plotted, this curve was the most regular and consistent graph obtained. Here too, it was the biodiesels which had an upper hand. The B80 biodiesel had the highest Mechanical Efficiency, followed by B60, B50, B40, and B20. The Mechanical efficiency of $100 \%$ diesel could only be placed at the last position, which strongly supports the upper hand of biodiesels over diesel.

The pollution test was another test planned to be conducted on the diesel engine, to solidify the statement of "Reduced polluting nature" of the biofuels. But due to technical reasons, the actual test could not be conducted. But on analysis of a measure of environmental pollution, the project team concentrated on the measurement of Exhaust Gas Temperature. All the biofuels had their EGT much lower than that of diesel. The B80 fuel with maximum content of biodiesel had the least EGT, followed by B60, B50, B40 and B20 biodiesels respectively. As the EGT reduces, the extent of pollution and corrosive effect also decreases. Hence we can certainly stress on the use of biodiesels as environment conservation is a major concern these days. It was also observed during the experiments that, there was a clear reduction in the visible emissions when the engine was run using biofuels. The visible emission was not even detected when the fuel used was B80 type.

An attempt to run the engine on pure biodiesel was also made during the experiments. But it was observed that, after running for a few minutes, the engine rpm reduced and the engine got shut off automatically. The engine was crank started again and analyzed. Once again the engine rpm dropped, but on manually opening up the governor to the full, the engine continued to operate as normal. It can be inferred that the engine shut off was due to lack of proper fuel spray into combustion chamber. On mere comparison of the fuel used,(B100 and other blends),

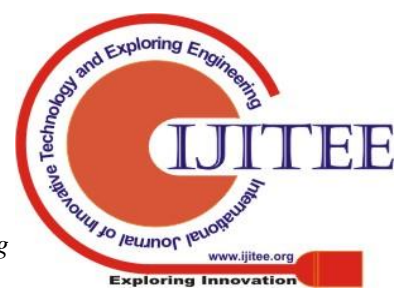


it can be easily seen that, the viscosity of B100 was much higher than that of the other fuels. Hence, it resulted in improper atomization and spray of fuel into combustion chamber. Therefore, we understand that, addition of diesel in small amounts to the biodiesels in necessary to reduce the viscosity to ensure a good fuel spray into combustion chamber.

As the overall engine performance is experimentally found to increase when biofuel was used, we can say that biofuels is utilized in diesel engines instead of diesel, with their most feasible range of $30 \%$ to $50 \%$ of biodiesel, along with diesel.

A proper technology for reducing the viscosity of biofuels can later remove the addition of diesel into the biofuels.

\section{REFERENCES}

1. W. Christopher ," The practical implementation of bio-diesel as an alternative fuel in service motor coaches",1997.

2. A. S. Ramadhas ,S. Jayaraj ,C. Muraleedharan ," Use of vegetable oils as IC engine fuels-a r review", Renewable energy,Vol.29,No.5,Apr.2004,pp.727-42.

3. K. Pramanik, "Properties and use of Jatropha curcas oil and diesel fuel blends in compression ignition engine". Renewable energy,Vol.28.No.2,Feb.2003,pp.239-48.

4. D. Agarwal ,A. K. Agarwal," Performance and emissions characteristics of Jatropha oil (preheated and blends) in a direct injection compression ignition engine", Applied thermal engineering,Vol.27,No.13,Sep.2007,pp.2314-23.

5. M. S. Radwan ,M. A. Ismail ,S. M. Elfeky ,O. S. Abu-Elyazeed,”. Jojoba methyl ester as a diesel fuel substitute: Preparation and characterization", Applied thermal engineering,Vol.27,No.2-3,Feb.2007,pp.314-22.

6. N. J. Barsic, A. L Humke," Performance and emissions characteristics of a naturally aspirated diesel engine with vegetable oil fuels", SAE Transactions, Jan. 1981,pp.1173-87.

7. K. Owen ,T. Coley," Automotive fuels reference book", 1995.

8. M. N. Nabi ,M. S. Akhter,M. M. Shahadat," Improvement of engine emissions with conventional diesel fuel and diesel-biodiesel blends", Bioresource Technology,Vol.97.No.3,Feb,pp.372-8.

9. A. Srivastava , R. Prasad, “ Triglycerides-based diesel fuels”, Renewable and sustainable energy reviews,Vol.4,No.2,Jun. 2000,pp.111-33.

10. K. Pramanik, "Properties and use of Jatropha curcas oil and diesel fuel blends in compression ignition engine". Renewable energy,Vol.28.No.2,Feb.2003,pp.239-48.

11. H. Zhang ,J. Wang ," Oil from biomass corncob tar as a fuel", Energy Conversion and Managemen,Vol.48,No.5,May. 2007,pp.:1751-7.

12. F. N. da Silva ,A. S. Prata ,J. R. Teixeira," Technical feasibility assessment of oleic sunflower methyl ester utilisation in Diesel bus engines", Energy conversion and management,Vol.44,No..18,Nov.2003,pp.2857-78.

13. C. L. Peterson ,T. Hustrulid ," Carbon cycle for rapeseed oil biodiesel fuels", Biomass and bioenergy,Vol.14,No.2,Mar.1998,pp.91-101.

14. P.Sathish kumar, R. Ramadoss,'INVESTIGATION OF MECHANICAL PROPERTIES AND TRIBOLOGICAL BEHAVIOUR OF BAGASSE FIBER REINFORCED POLYMER COMPOSITE", International Journal of MC Square Scientific Research, Vol.9, No.2, 2017,pp.86-96.

\section{AUTHORS PROFILE}

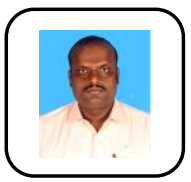

C .Thiagarajan - Associate ProfessorDepartment of Mechanical Engineering Aarupadai Veedu Institute of Technology Vinayaka Mission Research Foundation cthiagarajan@avit.ac.in

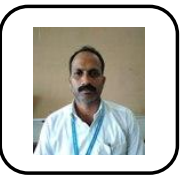

Surendrababu - profile Associate Professor Department of Mechanical Engineering Aarupadai Veedu Institute of Technology Vinayaka Mission Research Foundation surendrababu@avit.ac.in

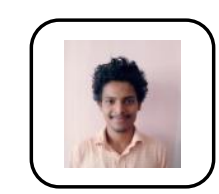

Vamsi Shankar UG Scholar Department of Mechanical Engineering Aarupadai Veedu Institute of Technology Vinayaka Mission Research Foundation.

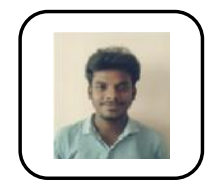

Saiprasanth UG Scholar Department of Mechanical Engineering Aarupadai Veedu Institute of Technology Vinayaka Mission Research Foundation

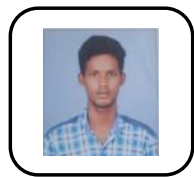

VenkateshKumar UG Scholar Department of Mechanical Engineering Aarupadai Veedu Institute of Technology Vinayaka Mission Research Foundation 